\title{
Analisa Pengaruh Kepatuhan Wajib Pajak Kendaraan Bermotor Kabupaten Wonogiri
}

\author{
Gede Ayu Sakura1), Arif Nugroho Rachman²) \\ ${ }^{1}$ Prodi Akuntansi, STIE Surakarta \\ email: ayusakurn@gmail.com \\ ${ }^{2}$ Prodi Akuntansi, STIE Surakarta \\ email: arifnugroho.rachman@gmail.com
}

\begin{abstract}
Abstrak
Wajib pajak berkewajiban dalam menjalankan serta melakukan pemenuhan hak perpajakan berdasarkan ketetapan yang diberlakukan secara baik juga benar dan tepat waktu membayar pajak dan mengetahui jatuh tempo dalam pembayaran. Penelitian yang dijalankan mempunyai tujuan guna mendeteksi pengaruh pengetahuan perpajakan, kualitas pelayanan, tingkat penghasilan serta sanksi perpajakan pada kepatuhan wajib pajak kendaraan bermotor di Kabupaten Wonogiri. Metode penelitian yang dipakai ialah pendekatan kuantitatif melalui jenis penelitian yang dipakai yakni studi kausal komparatif serta sumber data yang dipakai merupakan data primer. Populasi serta sampel yang digunakan merupakan wajib pajak yang ada pada kawasan Kabupaten Wonogiri dengan tehnik pengambilan sampel berupa purposive sampling melalui menetapkan beberapa kualifikasi tertentu melalui sebaran kuesioner. Tehnik analisis data yang dipakai ialah analisis regresi liner berganda. Hasil dari penelitian ini memperlihatkan mengenai variabel pengetahuan perpajakan serta kualitas pelayanan mempunyai pengaruh secara signifikan pada kepatuhan wajib pajak kendaraan bermotor dan variabel tingkat penghasilan serta sanksi perpajakan tidak mempunyai pengaruh pada kepatuhan wajib pajak kendaraan bermotor. Pengaruh secara simultan menunjukkan bahwa seluruh variabel bebas mempengaruhi dengan cara bersamaan pada ketaatan wajib pajak kendaraan bermotor.
\end{abstract}

Kata kunci : Pajak Kendaraan Bermotor; Perpajakan

\section{Analysis of the Influence of Motor Vehicle Taxpayer Compliance in Wonogiri Regency Abstract}

Taxpayers are obliged to implement and fulfill tax rights based on applicable provisions properly and correctly and on time in paying taxes and knowing the due date of payment. This study aims to determine the effect of tax knowledge, service quality, income level, and tax sanctions on motor vehicle taxpayer compliance in the Wonogiri Regency area. This research method uses a quantitative approach with the type of research used is a comparative causal study and the data source used is primary data. The population and sample used are taxpayers who are in the area of Wonogiri Regency with the sampling technique in the form of purposive sampling by determining certain criteria through questionnaires. The data analysis technique used is multiple linear regression analysis. The results of this study indicate that the tax knowledge variable and service quality have a significant effect on motor vehicle taxpayer compliance and the income level variable and tax sanctions have no effect on motor vehicle taxpayer compliance. The effect simultaneously shows that all independent variables have a joint effect on motor vehicle taxpayer compliance..

Keywords: Motor Vehicle Tax; Taxpayer

\section{Pendahuluan}

Menurut Undang-Undang No 28 Tahun 2009 kendaraan bermotor adalah kendaraan beroda yang beroperasi di daratan. Kendaraan bermotor digerakkan dengan mesin yang mengubah energi menjadi tenaga yang disesuaikan dengan mesin motor. Pajak yang dikenakan atas kepemilikan dan / atau penguasaan kendaraan bermotor merupakan pengertian pajak kendaraan bermotor menurut UU No 28 tahun 2009 pasal 12 dan 13. Salah satu pajak provinsi yang digunakan sebagai sumber

DOI: $10.25273 /$ inventory.vxix.8614

Copyright (C) 2021 Penulis

Sume rights reserved. 
pendapatan daerah ialah pajak kendaraan bermotor. Pajak tersebut penting karena digunakan bagi pembangunan daerah dan pembiayaan pemerintah.

Sumber pendapatan asli daerah Kabupaten Wonogiri yang cukup besar didapatkan dari pajak kendaraan bermotor. Pemerintah daerah perlu memperhatikan pertambahan kendaraan bermotor disetiap tahunnya. Tahun 2018 jumlah kendaraan bermotor di Kabupaten Wonogiri sejumlah 370.000 unit. Jumlah kendaraan bermotor selama 2 tahun terakhir, yaitu pada tahun 2018-2019 diketahui disetiap tahunnya terjadi pertambahan seperti berikut:

Tabel 1. Data Kendaraan Baru di Kabupaten Wonogiri pada Tahun 2018-2019

\begin{tabular}{lccc}
\hline Tahun & Sepeda Motor & Kendaraan Jenis lain & Total \\
\hline 2018 & 16.838 unit & 1.156 unit & 17.994 unit \\
2019 & 14.836 unit & 877 unit & 15.713 unit \\
Total & 31.674 unit & 2.033 unit & 33.707 unit \\
\hline
\end{tabular}

Sumber: Solopos.com

Warga Kabupaten Wonogiri pada tahun 2018-2019 diketahui membeli kendaraan baru baik kendaraan bermotor roda dua, roda empat, atau jenis lain dengan total keseluruhan mencapai 33.707 unit. Tabel 1 diketahui pada tahun 2018 jumlah kendaraan bermotor baru berupa sepeda motor sejumlah 16.838 unit dan kendaraan jenis lain sejumlah 1.156 unit dengan total keseluruhan 17.994 unit kendaraan baru. Tahun 2019 mengalami penurunan pembelian kendaraan baru, yaitu untuk jenis sepeda motor sejumlah 14.836 unit dan untuk jenis kendaraan lain sejumlah 877 unit dengan total keseluruhan 15.713 unit kendaraan baru. Penurunan pembelian kendaraan baru ini juga dibarengi dengan menurunnya total wajib pajak yang menunggak dalam membayar pajak kendaraan bermotor seperti dalam tabel dibawah:

Tabel 2. Data Wajib Pajak Kendaraan Bermotor di Kabupaten Wonogiri yang Menunggak dalam Membayar Pajak Kendaraan Bermotor Tahun 2018-2019

\begin{tabular}{ccc}
\hline Tahun & Jumlah Wajib Pajak & Total Tagihan \\
\hline 2018 & 32.000 wajib pajak & $7,1 \mathrm{M}$ \\
2019 & 27.424 wajib pajak & $6,6 \mathrm{M}$ \\
\hline
\end{tabular}

Sumber: Joglosemarnews.com

Tabel 2 tersebut dapat diketahui bahwa pada tahun 2018 total wajib pajak yang melakukan penunggakan semasa membayarkan pajak kendaraan bermotor sejumlah 32.000 wajib pajak dengan total tagihan sejumlah 7,1 M, dan pada tahun 2019 mengalami penurunan wajib pajak yang menunggak saat membayar pajak kendaraan bermotor sejumlah 4.576 wajib pajak dengan total penunggak pada tahun 2019 sejumlah 27.424 wajib pajak dengan total tagihan sejumlah 6,6 M. Tabel 1 dan tabel 2 diatas memperlihatkan bahwa jumlah pembelian kendaraan baru disetiap tahun mempengaruhi tidak sedikit wajib pajak yang menunggak saat membayarkan pajak kendaraan bermotor. Jumlah kendaraan baru tahun 2018 lebih banyak dibanding tahun 2019, begitu juga pada jumlah penunggak pada tahun 2018 lebih banyak dibanding tahun 2019. Merosotnya total wajib pajak yang menunggak dalam membayarkan pajak kendaraan bermotor dari tahun 2018 ke tahun 2019 berarti bahwa kepatuhan dalam membayar wajib pajak meningkat.

Beberapa faktor yang memberikan pengaruh bagi kepatuhan pembayaran pajak diantaranya, pengetahuan tentang pajak. Pemenuhan kewajiban membayar pajak harus dibarengi dengan pengetahuan perpajakan sebab konteks tersebut bisa menghasilkan dampak yang baik bagi wajib pajak. Pengetahuan ini akan membuat wajib pajak lebih mengenai pentingnya membayarkan pajak juga kegunaan yang bisa diperoleh jika pajak itu telah terbayarkan (Putra dan Jati, 2017). Faktor kedua adalah kualitas pelayanan. Kualitas pelayanan merupakan faktor internal yang memberikan pengaruh cukup besar kepada wajib pajak. Tingginya tingkat kepatuhan membayar pajak harus dibarengi dengan semakin baiknya kualitas layanan pembayaran pajak. Pelayanan yang dimaksudnya disini contohnya seperti pelaporan, pengisian, dan penyetoran pajak dari wajib pajak (Lestari, 2016). 
Faktor ketiga adalah tingkat penghasilan. Tingkat penghasilan berpengaruh dalam ketepatan waktu pembayaran pajak. Masyarakat yang memiliki penghasilan terbatas akan lebih memilih untuk melengkapi kebutuhan sehari-hari terlebih dahulu dibanding membayar pajak tepat pada waktunya, akan tetapi masih ada masyarakat yang menyisihkan pendapatan mereka untuk membayarkan pajak tepat pada waktunya yang sudah ditetapkan. Faktor keempat adalah sanksi perpajakan. Hukum yang telah ditetapkan akan selalu ada sanksi bagi pihak yang tidak menjalankan sesuai hukum yang berlaku termasuk pada pajak kendaraan bermotor. Sanksi perpajakan merupakan sebuah faktor yang bisa mendongkrak peningkatan ketaatan wajib pajak kendaraan bermotor. Sanksi perpajakan digunakan sebagai perantara supaya para wajib pajak tidak terlambat dan seusai waktu dalam pembayaran pajak.

Penelitian ini sudah dijalankan oleh sejumlah peneliti terdahulu seperti pada penelitian yang berjudul sejumlah faktor yang memberikan pengaruh ketaatan wajib pajak saat membayarkan pajak kendaraan bermotor. Penelitian tersebut menggunakan 3 variabel bebas yakni wawasan perpajakan, sosialisasi perpajakan serta penerapan e-samsat dan variabel terikat yakni ketaatan wajib pajak. Penelitian ini menunjukkan dengan cara simultan ataupun parsial wawasan perpajakan, sosialisasi pajak serta penerapan e-samsat mempengaruhi secara signifikan pada ketaatan wajib pajak kendaraan bermotor. Faktor dominan yang memberikan pengaruh ketaatan wajib pajak saat membayarkan pajak kendaraan bermotor ialah variabel penerapan e-samsat yakni sejumlah 49.9 persen. Penelitian ini dilakukan oleh Wuryanto (2019).

Penelitian yang dijalankan oleh Ilhamsyah, Randi (2016) berjudul pengaruh pengertian serta wawasan wajib pajak mengenai regulasi perpajakan, kesadaran wajib pajak, mutu pelayanan serta sanksi perpajakan pada kepatuhan wajib pajak kendaraan bermotor (studi samsat kota malang) digunakan empat variabel bebas antara lain: (1) wawasan serta pengertian mengenai regulasi perpajakan wajib pajak (2) kesadaran wajib pajak (3) mutu pelayanan serta (4) sanksi perpajakan. Variabel terikat yang dipakai dalam penelitian yang dijalankan yaitu ketaatan wajib pajak. Hasil dari penelitian yang dijalankan ialah wawasan serta pengertian wajib pajak mengenai regulasi perpajakan, rasa sadar wajib pajak, mutu pelayanan serta sanksi perpajakan berpengaruh signifikan pada ketaatan wajib pajak kendaraan bermotor yang tercatat pada Kantor Bersama Samsat Kota Malang.

Persamaan penelitian sebelumnya pada penelitian pada saat ini yaitu dalam variabel terikat yang digunakan merupakan kepatuhan wajib pajak dan ketidaksamaan penelitian yang dijalankan pada terdahulu sebelumnya, peneliti menggunakan empat variabel bebas yakni pengetahuan perpajakan, kualitas pelayanan, tingkat penghasilan, dan sanksi perpajakan serta pemilihan tahun,lokasi penelitian, populasi serta sampel penelitian. Penelitian ini berdasarkan peristiwa wajib pajak kendaraan bermotor yang tercatat pada Kantor UPPD Kabupaten Wonogiri, yang mana pada tahun 2018 dan 2019 adanya pertambahan kendaraan baru tetapi penunggak yang membayar pajak kendaraan bermotor mengalami penurunan. Rumusan permasalahan terkait fenomena diatas yaitu faktor apakah yang memberikan pengaruh kepatuhan wajib pajak saat membayarkan pajak kendaraan bermotor. Tujuan penelitian yang dijalankan ialah guna mendeteksi pengaruh pengetahuan perpajakan, kualitas pelayanan, tingkat penghasilan serta sanksi perpajakan pada kepatuhan wajib pajak kendaraan bermotor dan diperoleh judul dalam penelitian yang dijalankan adalah analisa pengaruh kepatuhan wajib pajak kendaraan bermotor Kabupaten Wonogiri.

\section{Metode Penelitian}

Pendekatan kuantitatif dipakai pada penelitian ini sebab dalam proses analisa data menggunakan pengolahan statistik. Pendekatan kuantitatif merupakan metode penelitian yang dipakai guna melakukan penelitian suatu populasi atau sampel yang sudah ditentukan, yang mana instrumen penelitian digunakan sebagai pengumpulan data, analisis data yang mempunyai sifat statisitik, bertujuan guna melakukan pengujian hipotesis yang sudah ditentukan (Sugiyono, 2017). Jenis penelitian yang digunakan yaitu studi kausal komparatif (causal comperative research). Studi kausal komparatif merupakan penelitian yang melakukan penyelidikan adanya relasi kasualitas sesuai dengan pemantauan serta melakukan pencarian sebab yang menjadi penyebab lewat sebuah data (Noor, 2107). Sumber data pada penelitian yang dijalankan memakai data primer yang adalah data yang didapatkan langsung melalui responden serta dilakukan pencatatan kali pertama (Sugiyono, 2018). Data yang digunakan merupakan hasil dari sebaran pertanyaan-pertanyaan kepada responden dalam bentuk kuesioner. Kuesioner adalah tehnik mengumpulkan data melalui pemberian sejumlah pertanyaan pada responden (Sugiyono, 2017). Kuisioner pada penelitian ini tersusun atas beberapa bagian yang mana bagian pertama adalah identitas responden misalnya nama, jenis kelamin, umur, 
jenis kendaraan (roda dua atau roda empat), dan bagian berikutnya merupakan pertanyaan tertutup yang terkait dengan kepatuhan wajib pajak kendaraan bermotor.

Populasi merupakan objek yang memiliki mutu serta ciri-ciri yang telah peneliti tetapkan guna dipelajari serta disimpulkan. Sampel merupakan bagian pada total serta ciri-ciri yang populasi miliki (Sugiyono, 2017). Populasi pada penelitian ini memiliki jumlah yang tidak terbatas karena jumlah objek yang naik turun sehingga tidak menentu angkanya. Sampel pada penelitian ini merujuk pada Roscoe yang berupa "ukuran sampe melebihi 30 serta tak melampaui 500 ialah pas bagi banyak penelitian" sehingga peneliti menetapkan untuk memilih sampel sejumlah 100 responden. Populasi serta sampel dalam penelitian yang dijalankan ialah wajib pajak kendaraan yang ada dalam Kabupaten Wonogiri.

Penelitian ini memakai teknik purpose sampling untuk melakukan pengambilan sampel. Purposive sampling adalah tehnik pengambilan sampel melalui sebuah pertimbangan (Sugiyono, 2017). Purposive sampling ditetapkan oleh peneliti sebagai tehnik pengambilan sampel karena pada penelitian ini didapatkan sejumlah kriteria yang ditujukan kepada objek yang akan menjadi responden. Kriteria yang sudah peneliti tentukan diantaranya:

1. Wajib pajak yang mempunyai kendaraan bermotor dan tercatat dalam Kantor UPPD Kabupaten Wonogiri. Calon responden apabila tidak memiliki kendaraan bermotor atau kendaraan yang dimiliki tidak terdaftar di Kantor UPPD Kabupaten Wonogiri, maka akan diganti responden lainnya yang sesuai dengan kriteria yang telah ditentukan.

2. Wajib pajak yang membayarkan pajak kendaraan bermotor baik dalam Kantor Samsat Pembantu Purwantoro, Kantor Samsat Pembantu Baturetno, maupun Kantor Samsat Wonogiri.

\section{Definisi Variabel dan Pengukuran Variabel}

Segala sesuatu yang diamati dan digunakan untuk memperoleh informasi dan menarik kesimpulan biasa disebut dengan variabel (Sugiyono, 2017). Penelitian yang dijalankan tersusun atas sebuah variabel terikat (dependen) serta 4 variabel bebas (independen). Pengukuran variabel menggunakan skala likert dengan skala 5 poin disetiap indikator untuk menentukan jawaban responden, yakni:

$\begin{array}{ll}\text { Sangat Setuju (SS) } & \text { : Poin 5 } \\ \text { Setuju (S) } & \text { : Poin } 4 \\ \text { Netral (N) } & \text { : Poin 3 } \\ \text { Tidak setuju (TS) } & \text { : Poin 2 } \\ \text { Sangat Tidak Setuju (STS) } & \text { : Poin 1 }\end{array}$

1. Variabel Terikat (Dependen Y)

Variabel terikat atau dependen ialah variabel yang diberikan pengaruh melalui variabel bebas (Sugiyono, 2017). Variabel terikat penelitian ini ialah kepatuhan wajib pajak. Kepatuhan/ketaatan wajib pajak adalah kewajiban wajib pajak dalam memberikan kontribusi pada negara yang dijalankan dengan keikhlasan (Mukmin dan Maemunah, 2019). Kepatuhan wajib pajak dilakukan untuk mematuhi aturan perpajakan seperti administrasi dan pemungutan pajak. Ketaatan wajib pajak sebagai aspek yang utama sebab apabila tidak ada kepatuhan wajib pajak sehingga mengakibatkan ketinggian pajak terutang wajib pajak yang memberikan dampak bagi tak dipenuhinya capaian penerimaan pajak daerah melalui pajak kendaraan bermotor. Indikator kepatuhan wajib pajak (Melani dan Susanti, 2018):

a. Pemenuhan pajak berdasar regulasi.

b. Pembayaran tepat waktu.

c. Memenuhi persyaratan.

d. Mengetahui jatu tempo.

2. Variabel Bebas (Independen X)

Penyebab adanya variabel dependent atau perubahan disebabkan oleh variabel independen (Sugiyanto, 2017). Variabel independen dalam penelitian yang dijalankan diantaranya: 
a. Pengetahuan Perpajakan $\left(\mathrm{X}_{1}\right)$

Pengetahuan perpajakan adalah informasi dasar bagi wajib pajak sebelum bertindak dan mengambil keputusan dalam kewajibannya sebagai wajib pajak. Wawasan perpajakan yang wajib pajak punya bisa membantu menaikkan tingkat ketaatan wajib pajak saat membayarkan pajak kendaraan bermotor (Wardani dan Rumiyatun, 2017). Indikator pengetahuan perpajakan (Dewi Kusuma Wardani dan Rumiyatun, 2017):

1) Memahami fungsi pajak.

2) Prosedur perpajakan kendaraan bermotor.

3) Pengenaan sanksi atas keterlambatan pembayaran.

4) Pembayaran pajak dapat dilakukan dikantor Samsat Pembantu Purwantoro, Kantor Samsat Pembantu Baturetno, atau Kantor Samsat Kabupaten Wonogiri.

b. Kualitas Pelayanan $\left(\mathrm{X}_{2}\right)$

Kualitas pelayanan merupakan baik buruknya prosedur pelayanan yang fiskus berikan kepada wajib pajak (Muhammad Iqbal, 2018). Mutu pelayanan yang diberi semakin baik sehingga bisa melakukan peningkatan ketaatan wajib pajak kendaraan bermotor. Indikator kualitas pelayanan (Fatmawati, 2016):

1) Kenyamanan ruang pelayanan.

2) Ketepatan dan ketanggapan petugas.

3) Alur pembayaran.

4) Waktu tunggu antrian.

c. Tingkat Penghasilan $\left(\mathrm{X}_{3}\right)$

Tingkat penghasilan berpengaruh cukup besar bagi tingkat ketaatan wajib pajak saat membayarkan pajak kendaraan bermotor. Kewajiban wajib pajak saat membayarkan pajak berkaitan kuat pada penghasilan yang mereka miliki. Wajib pajak yang kurang mampu akan lebih mengutamakan untuk memenuhi kebutuhan sehari-hari terlebih dahulu dibanding untuk membayarkan pajak kendaraan bermotor. Indikator tingkat penghasilan (Muchlis, 2018):

1) Hubungan kemampuan wajib pajak saat membayarkan pajak melalui penghasilan yang dimiliki.

2) Kesesuaian pajak yang dibebankan dengan penghasilan yang dimiliki.

3) Kesanggupan wajib pajak atas biaya yang dikenakan.

4) Kesediaan wajib pajak dalam membayar meskipun pendapatan rendah.

d. Sanksi Perpajakan $\left(\mathrm{X}_{4}\right)$

Sanksi perpajakan biasa digunakan untuk mencegah wajib pajak dalam melanggar aturan (Mardiasmo, 2018). Sanksi perpajakan dilaksanakan agar dipenuhinya kewajiban perpajakan melalui wajib pajak. Wajib pajak bisa taat sebab keberadaan sanksi berat berbentuk denda administrasi bagi wajab pajak yang tidak membayarkan pajaknya sesuai dengan waktu yang telah ditetapkan. Indikator sanksi perpajakan (Tri Julianti, 2017):

1) Penegakan kepatuhan adanya sanksi.

2) Ketegasan atas pengenaan sanksi.

3) Jatuhnya sanksi yang diberikan berdasar perbuatan yang dilakukan.

4) Pengenaan sanksi sesuai aturan berlakukan.

\section{Alat Analisis Data}

Pada penelitian yang dijalankan memakai alat analisis regresi linier berganda. Proses perhitungan akan menggunakan apikasi software Statistical Program for Social Science (SPSS) versi 22. Analisis regresi linier berganda dipakai guna mendeteksi keberadaan pengaruh melalui variabel bebas pada variabel terikat. Analisis yang perlu dilakukan sebelum pengujian hipotesis, antara lain:

1. Uji Validitas dan Uji Reliabilitas

2. Uji Asumsi Klasik yang digunakan uji normalitas, uji multikolinearitas, serta uji heteroskedastisitas.

3. Uji Regresi Linier Berganda

Persamaan regresi linier berganda

$Y=a+b_{1} X_{1}+b_{2} X_{2}+b_{3} X_{3}+b_{4} X_{4}+e$ 


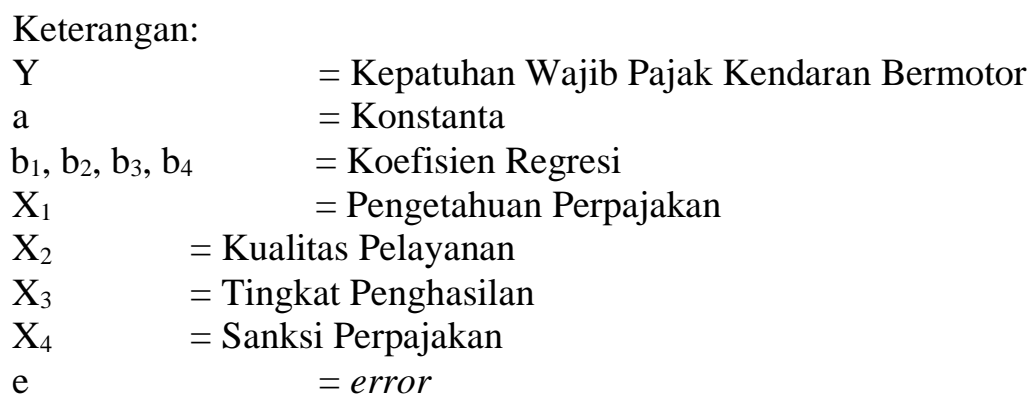

4. Uji Hipotesis yang digunakan yaitu uji determinasi $\left(\mathrm{R}^{2}\right)$, uji $\mathrm{f}$, dan uji t.

\section{Hasil Dan Pembahasan}

Data pada penelitian ini didapatkan melalui kuisioner yang sudah dilakukan pengisian melalui wajib pajak kendaraan bermotor yang berada pada wilayah Kabupaten Wonogiri. Kuesioner disebarkan melalui link kepada calon responden. Hasil sebaran kuesioner yang diperoleh, ditemukan beberapa jawaban responden yang tidak dapat digunakan untuk pengujian hipotesis seperti berikut:

\section{Tabel 3. Distribusi Kuesioner Penelitian}

\begin{tabular}{lc}
\hline \multicolumn{1}{c}{ Keterangan } & Jumlah Responden \\
\hline Sampel yang didapat & 106 \\
Sampel yang memenuhi kriteria & 100 \\
Sampel yang outlier & 13 \\
Sampel yang digunakan uji hipotesis & 87 \\
\hline Karakteristik sampel responden yang dapat digunakan untuk uji hipotesis dikelompokkan
\end{tabular}

Karakteristik sampel responden yang dapat digunakan untuk uji hipotesis dikelompokkan menurut jenis kelamin, umur, pendidikan terakhir, jenis kendaraan seperti dibawah ini:

Tabel 4. Karakteristik Responden

\begin{tabular}{lcc}
\hline \multicolumn{1}{c}{ Karakteristik } & Frekuensi (Responden) & Persentase (\%) \\
\hline Jenis Kelamin & 46 & 53 \\
Laki-laki & 41 & 47 \\
Perempuan & 87 & 100 \\
Total & & \\
Umur & 10 & 11 \\
$<21$ Tahun & 67 & 77 \\
$21-30$ Tahun & 8 & 10 \\
$31-40$ Tahun & 1 & 1 \\
$41-50$ Tahun & 1 & 1 \\
50 Tahun & 87 & 100 \\
Total & & \\
Pendidikan Terakhir & 0 & 0 \\
SD & 6 & 7 \\
SMP & 34 & 39 \\
SMA/SMK & 47 & 54 \\
Sarjana/Diploma & 87 & 100 \\
Total & & \\
Jenis Kendaraan & 76 & 87 \\
Roda Dua & 11 & 13 \\
Roda Empat & 87 & 100 \\
Total & \multicolumn{1}{c}{ Tabl 4 ters } & \\
\hline
\end{tabular}

Tabel 4 tersebut diketahui bahwa dari 87 responden yang telah terpilih dikuasai oleh laki-laki sejumlah 46 responden atau 53\%. Rentang umur responden yang terbanyak ialah antara umur $21-30$ tahun sejumlah 67 responden maupun $77 \%$. Pendidikan terakhir yang didapatkan kebanyakan dari 
responden yakni sarjana/diploma sejumlah 47 responden atau 54\%. Jenis kendaraan yang dimiliki responden terbanyak pada roda dua dengan jumlah 76 responden atau $87 \%$.

Uji Validitas

Tabel 5. Uji Validitas Variabel

\begin{tabular}{llll}
\hline \multicolumn{1}{c}{ Keterangan } & $\mathbf{r}_{\text {hitung }}$ & Sig. & $\mathbf{r}_{\text {tabel }}(\mathbf{0 , 0 5})$ \\
\hline Y & & & \\
Y.1 & .751 & .000 & .210 \\
Y.2 & .782 & .000 & .210 \\
Y.3 & .845 & .000 & .210 \\
Y.4 & .818 & .000 & .210 \\
X1 & & & \\
X1.1 & .776 & .000 & .210 \\
X1.2 & .766 & .000 & .210 \\
X1.3 & .665 & .000 & .210 \\
X1.4 & .728 & .000 & .210 \\
X2 & & & \\
X2.1 & .822 & .000 & .210 \\
X2.2 & .883 & .000 & .210 \\
X2.3 & .804 & .000 & .210 \\
X2.4 & .778 & .000 & .210 \\
X3 & & & \\
X3.1 & .727 & .000 & .210 \\
X3.2 & .757 & .000 & .210 \\
X3.3 & .711 & .000 & .210 \\
X3.4 & .610 & .000 & .210 \\
X4 & & & \\
X4.1 & .758 & .000 & .210 \\
X4.2 & .872 & .000 & .210 \\
X4.3 & .737 & .000 & .210 \\
X4.4 & .802 & .000 & .210 \\
Kr & & & \\
\hline
\end{tabular}

Kriteria pengambilan keputusan dalam uji validitas ialah jika $r_{\text {hitung }}$ melebihi $r_{\text {tabel }}$ sehingga variabel tersebut valid dan apabila $r_{\text {hitung }}$ kurang dari maupun tak melampaui $r_{\text {tabel }}$ sehingga variabel itu disebutkan tak valid. $R_{\text {tabel }}$ pada penelitian ini telah ditetapkan bahwa nilai signifikan sejumlah 0,05 dengan jumlah responden sejumlah 87. Penarikan nilai $\mathrm{r}_{\text {tabel }}$ yang telah diperhitungkan dengan rumus yang telah ditetapkan yaitu jumlah df sejumlah 85 ( $\mathrm{N}$ atau jumlah responden -2 ) memperoleh nilai $\mathrm{r}_{\text {tabel }} 0,210$. Tabel 5 tersebut bisa dipantau mengenai nilai $\mathrm{r}_{\text {hitung }}$ disetiap variabel nilainya melampaui dari $r_{\text {tabel }} 0,05$ yang memiliki nilai 0,210 . Variabel $Y>r_{\text {tabel. }}$. Variabel $X 1>r_{\text {tabel. }}$ Variabel $X 2>r_{\text {tabel. }}$. Variabel X3 $>\mathrm{r}_{\text {tabel. }}$. Variabel X4 $>\mathrm{r}_{\text {tabel. }}$. Hasil dari uji validitas pada penelitian yang dijalankan bisa dikatakan bahwa semua variabel yang digunakan ialah valid.

Uji Reliabilitas

Tabel 6. Hasil Uji Reliabilitas Variabel

\begin{tabular}{lccc}
\hline \multicolumn{1}{c}{ Variabel } & Indikator & Cronbach's Alpha & Keterangan \\
\hline Y Kepatuhan Wajib Pajak & 4 & .800 & Reliabel \\
X1 Pengetahuan Perpajakan & 4 & .696 & Reliabel \\
X2 Kualitas Pelayanan & 4 & .826 & Reliabel \\
X3 Tingkat Penghasilan & 4 & .653 & Reliabel \\
X4 Sanksi Perpajakan & 4 & .796 & Reliabel \\
\hline
\end{tabular}

Kriteria pengambilan keputusan pada uji reliabel dapat dilihat pada nilai cronbach's alpha melebihi 0,6. Nilai cronbach's alpha yang melebihi sama dengan 0,6 berarti reliabel, dan apabila kurang dari 0,6 maka belum reliabel. Tabel 6 di atas dapat dilihat pada variabel Y dengan jumlah indikator 4 pertanyaan mempunyai nilai cronbach's alpha 0,800 yang mana dapat diketahui bahwa $0,800>0,6$ artinya jawaban responden terhadap 4 pertanyaan tersebut adalah konsisten dan indikator dapat dihandalkan (reliabel). Variabel $\mathrm{X}_{1}$ dengan jumlah indikator 4 pertanyaan mempunyai nilai cronbach's alpha 0,696 yang mana bisa diketahui mengenai 0,696>0,6 artinya jawaban responden terhadap 4 pertanyaan tersebut adalah konsisten dan indikator dapat dihandalkan (reliabel). Variabel 
$\mathrm{X}_{2}$ dengan jumlah indikator 4 pertanyaan memiliki nilai cronbach's alpha 0,826 yang mana dapat diketahui bahwa $0,826>0,6$ artinya jawaban responden terhadap 4 pertanyaan tersebut adalah konsisten dan dapat dihandalkan (reliabel). Variabel $\mathrm{X}_{3}$ dengan jumlah indikator 4 pertanyaan mempunyai nilai cronbach's alpha 0,653 yang mana dapat diketahui bahwa 0,653 > 0,6 artinya jawaban responden terhadap 4 pertanyaan tersebut adalah konsisten dan dapat dihandalkan (reliabel). Variabel $\mathrm{X}_{4}$ dengan jumlah indikator 4 pertanyaan mempunyai nilai cronbach's alpha 0,796 yang mana dapat diketahui bahwa 0,796 >0,6 artinya jawaban responden pada 4 pertanyaan tersebut adalah konsisten dan dapat dihandalkan (reliabel). Variabel yang dipakai dalam penelitian yang dijalankan bisa dikatakan bahwa semua variabel memiliki hasil reliabel.

Uji Normalitas

Tabel 7. Hasil Uji Normalitas

\begin{tabular}{llr}
\hline \multicolumn{2}{c}{ One-Sample Kolmogorov-Smirnov Test } \\
\hline & & \multicolumn{2}{c}{ Unstandardized } \\
Residual \\
$\mathrm{N}$ & & \multicolumn{1}{c}{} \\
Normal Parameters ${ }^{\mathrm{a}, \mathrm{b}}$ & Mean & 87 \\
& Std. Deviation & .0000000 \\
Most Extreme Differences & Absolute & 1.38073902 \\
& Positive & .086 \\
Test Statistic & Negative & .064 \\
Asymp. Sig. (2-tailed) & & -.086 \\
\hline Kry & & .086 \\
& & $.158^{\mathrm{c}}$ \\
\hline
\end{tabular}

Kriteria yang digunakan pada uji normalitas di penelitian ini dengan memperhatikan nilai asymp melebihi 0,05 . Nilai asymp yang melebihi 0,05 bisa dikatakan data terdistribusi normal, jika nilai asymp kurang dari 0,05 sehingga bisa disebutkan data tak terdistribusi normal. Tabel 7 tersebut dideteksi nilai asymp 0,158 sehingga diperoleh $0,158>0,05$ berarti data pada penelitian ini terdistribusi dengan cara normal.

\section{Uji Multikolinearitas}

Tabel 8. Hasil Uji Multikolinearitas

\begin{tabular}{|c|c|c|}
\hline \multirow[b]{2}{*}{ Model } & \multicolumn{2}{|c|}{ Collinearity Statistics } \\
\hline & Tolerance & VIF \\
\hline (Constant) & & \\
\hline Pengetahuan Perpajakan & 645 & 1,550 \\
\hline Kualitas Pelayanan & 617 & 1,621 \\
\hline Tingkat Penghasilan & .660 & 1,515 \\
\hline Sanksi Perpajakan & .702 & 1,425 \\
\hline
\end{tabular}

Hasil uji multikolinearitas ini memiliki arti mengenai seluruh variabel pada penelitian ini tak terjadi permasalahan multikolinearitas. Tabel 8 tersebut memperlihatkan mengenai seluruh data yang diperoleh nilai tolerance melampaui 0,10 serta nilai VIF tak melampaui 10,00.

\section{Uji Heteroskedastisitas}

Tabel 9. Hasil Uji Heteroskedastisitas

\begin{tabular}{ll}
\hline Model & Sig \\
\hline (Constant) & .180 \\
Pengetahuan Perpajakan & .653 \\
Kualitas Pelayanan & .779 \\
Tingkat Penghasilan & .478 \\
Sanksi Perpajakan & \\
\hline
\end{tabular}

Hasil uji ini memakai uji glejser yang memperlihatkan mengenai seluruh variabel bebas mempunyai nilai sig melebihi 0,05 berarti variabel yang digunakan tidak mengalami gejala heteroskedastisitas. 
Tabel 10. Coefficients

\begin{tabular}{|c|c|c|c|c|c|c|}
\hline \multirow{2}{*}{\multicolumn{2}{|c|}{ Model }} & \multicolumn{2}{|c|}{$\begin{array}{l}\text { Unstandardized } \\
\text { Coefficients }\end{array}$} & \multirow{2}{*}{$\begin{array}{l}\text { Standardized } \\
\text { Coefficients } \\
\text { Beta }\end{array}$} & \multirow[b]{2}{*}{$\mathrm{T}$} & \multirow[b]{2}{*}{ Sig. } \\
\hline & & B & Std. Error & & & \\
\hline \multirow[t]{6}{*}{1} & (Constant) & 9.737 & 1.643 & & 5.926 & .000 \\
\hline & Pengetahuan & .305 & .094 & .366 & 3.243 & .002 \\
\hline & Perpajakan & & & & & \\
\hline & Kualitas Perpajakan & .166 & .079 & .244 & 2.114 & .038 \\
\hline & Tingkat Penghasilan & -.128 & .087 & -.164 & -1.466 & .146 \\
\hline & Sanksi Perpajakan & .153 & .091 & .181 & 1.676 & .098 \\
\hline
\end{tabular}

Hasil olah data penelitian yang dijalankan memakai program SPSS for Windows Versi 22 didapatkan hasil seperti pada tabel 9 di atas dengan persamaan regresi seperti dibawah ini:

$$
\mathrm{Y}=9,737+0,305 \mathrm{X}_{1}+0,166 \mathrm{X}_{2}-0,128 \mathrm{X}_{3}+0,153 \mathrm{X}_{4}+\mathrm{e}
$$

Hasil regresi yang didapatkan bisa dipaparkan arti koefisien regresi diantaranya:

1. $\mathrm{a}=9,737$

Menunjukkan nilai konstanta dari kepatuhan wajib pajak yang berarti jika pengaruh pengetahuan perpajakan, kualitas pelayanan, tingkat penghasilan, dan sanksi perpajakan $=0$, maka nilai kepatuhan wajib pajak sejumlah 9,737.

2. $\mathrm{b}_{1}=0,305$

Mengartikan pengetahuan perpajakan $\left(\mathrm{X}_{1}\right)$ meningkat sehingga kepatuhan wajib pajak (Y) meningkat sejumlah 0,305 satuan dengan memiliki arah positif.

3. $\mathrm{b}_{2}=0,166$

Mengartikan kualitas pelayanan $\left(\mathrm{X}_{2}\right)$ meningkat sehingga kepatuhan wajib pajak (Y) meningkat sejumlah 0,166 satuandengan memiliki arah positif.

4. $\mathrm{b}_{3}=-0,128$

Mengartikan tingkat penghasilan $\left(\mathrm{X}_{3}\right)$ meningkat sehingga kepatuhan wajib pajak akan turun sejumlah 0,128 satuan dengan memiliki arah negatif.

5. $\mathrm{b}_{4}=0,153$

Mengartikan sanksi perpajakan $\left(\mathrm{X}_{4}\right)$ meningkat sehingga kepatuhan wajib pajak meningkat sejumlah 0,153 satuan dengan memiliki arah positif.

\section{Uji Koefisien Determinasi}

Tabel 11. Koefisien Determinasi Model Summary

\begin{tabular}{cc}
\hline R Square & Adjusted R Square \\
\hline .326 & .293 \\
\hline
\end{tabular}

Tabel 11 tersebut dideteksi mengenai hasil dari Adjusted $R$ Square sejumlah 0,293 atau 29,3\%. Dari uji determinasi ini dapat diketahui bahwa variabel bebas berpengaruh secara menyeluruh kepada kepatuhan wajib pajak kendaraan bermotor dengan persentase hasil sejumlah $29,3 \%$ dan sisanya $70,7 \%$ dipengaruhi oleh variabel yang yang tidak digunakan pada penelitian ini.

\section{Uji T}

Tabel 12. Hasil Uji T

\begin{tabular}{llrr} 
Model & $\mathrm{t}$ & Sig. \\
\hline 1 & (Constant) & 5.926 & .000 \\
& Pengetahuan & 3.243 & .002 \\
& Perpajakan & & \\
& Kualitas Perpajakan & 2.114 & .038 \\
& Tingkat Penghasilan & -1.466 & .146 \\
& Sanksi Perpajakan & 1.676 & .098 \\
\hline
\end{tabular}

Tabel 12 di atas menunjukkan hasil perhitungan dari Uji T menggunakan SPSS for Windows Versi 22 didapatkan hasil diantaranya:

1. Variabel Pengetahuan Perpajakan $\left(\mathrm{X}_{1}\right)$ diperoleh t hitung 3,242>1,987 (t tabel) dan nilai sig sejumlah $0,002<0,05$ berarti ada pengaruh dengan cara signifikan parsial tehadap kepatuhan wajib pajak. 
2. Variabel Kualitas Pelayanan $\left(\mathrm{X}_{2}\right)$ diperoleh $\mathrm{t}$ hitung $2,114>1,987$ (t tabel) dan sig 0,038< 0,05 berarti ada pengaruh secara signifikan parsial pada kepatuhan wajib pajak.

3. Variabel Tingkat Penghasilan $\left(X_{3}\right)$ diperoleh t hitung $-1,466<1,987$ dan sig $0,146>0,05$ berarti tidak ada pengaruh pada kepatuhan wajib pajak.

4. Variabel Sanksi Perpajakan $\left(\mathrm{X}_{4}\right)$ diperoleh t hitung 1,676 $<1,987$ dan sig 0,098 $>0,05$ berarti tidak ada pengaruh pada kepatuhan wajib pajak.

Uji F

Tabel 13. Hasil Uji F

\begin{tabular}{ccc}
\hline Model & F & Sig. \\
\hline Regression & 9.896 & .000 \\
\hline
\end{tabular}

Tabel 13 di atas menunjukkan adanya pengaruh simultan (bersama-sama) variabel pengetahuan perpajakan, kualitas pelayanan, tingkat penghasilan, dan sanksi perpajakan berpengaruh signifikan dengan cara bersamaan (simultan) pada variabel kepatuhan wajib pajak dengan melihat nilai sig 0,000 $<0,05$.

\section{Pembahasan}

\section{Pengaruh Pengetahuan Perpajakan pada Kepatuhan Wajib Pajak}

Hasil analisa didapat dari uji t dengan nilai t sejumlah 3,243 dan signifikansi 0,002 tidak melampaui 0,05 berarti ada pengaruh antara variabel pengetahuan perpajakan bagi ketaatan wajib pajak. Makin tinggi pengetahuan perpajakan yang wajib pajak punya sehingga kian tinggi juga ketaatan wajib pajak dalam membayar pajak kendaraan bermotor. Rata-rata jawaban responden merata di semua pertanyaan yaitu wajib pajak mengetahui bahwa pembiayaan pembangunan daerah merupakan salah satu fungsi dari pajak, wajib pajak telah mengetahui langkah-langkah dalam membayar pajak kendaraan bermotor serta mengetahui bahwa sanksi akan diberikan jika terlambat saat membayarkan pajak, wajib pajak dapat membayarkan pajaknya baik di kantor samsat pembantu maupun di kantor samsat di Kabupaten Wonogiri. Tanggapan responden menunjukkan bahwa wajib pajak di Kabupaten Wonogiri memiliki kesadaran dan mengerti akan pengetahuan perpajakan. Hasil penelitian ini mendukung penelitian sebelumnya yang telah dilakukan oleh Wuryanto (2019) dengan judul penelitian sejumlah faktor yang memberikan pengaruh ketaatan wajib pajak saat membayarkan pajak kendaraan bermotor. Pada penelitian ini diketahui bahwa kedisplinan dalam pembayaran wajib pajak kendaraan bermotor dipengaruhi secara positif dan signifikan parsial oleh pengetahuan tentang perpajakan.

\section{Pengaruh Kualitas Pelayanan pada Kepatuhan Wajib Pajak}

Hasil analisa didapat dari uji $\mathrm{t}$ dengan nilai $\mathrm{t}$ sejumlah 2,114 dan signifikansi 0,038 tidak melampaui 0,05 berarti ada pengaruh antara variabel kualitas pelayanaan dengan kepatuhan wajib pajak. Semakin tinggi kualitas pelayanan yang diberikan oleh fiskus bisa menambah kepatuhan wajib pajak saat membayarkan pajak kendaraan bermotor pada wilayah Kabupaten wonogiri. Rata-rata jawaban responden merata disemua pertanyaan yaitu ruangan pelayanan pada kantor samsat memadai dan memberi kenyamanan pada wajib pajak, petugas tanggap dan tepat dalam melayani, alur pembayaran dan waktu tunggu antrian tidak berbelit-belit dan cukup cepat. Tanggapan responden ini memperlihatkan mengenai mutu pelayanan yang diberikan telah benar. Semakin baik pemberian mutu pelayanan sehingga wajib pajak akan memberikan sikap positif dan semakin patuh dalam membayar pajak kendaraan bermotor. Hasil penelitian ini sejalan dengan penelitian sebelumnya yang dilakukan oleh Randi Ilhamsyah (2016) judul penelitian adalah pemahaman wajib pajak dan dampak peraturan perpajakan, kesadaran wajib pajak, kualitas pelayanan, dan sanksi perpajakan pada kepatuhan wajib pajak kendaraan bermotor. Hasil penelitiannya memperlihatkan mengenai variabel mutu pelayanan memberikan pengaruh secara signifikan pada kepatuhan wajib pajak kendaraan bermotor.

\section{Pengaruh Tingkat Penghasilan pada Kepatuhan Wajib Pajak}

Hasil analisa didapat dari uji t dengan nilai t sejumlah -1,466 dan signifikansi 0,146 melebihi 0,05 berarti tidak terdapat pengaruh antara tingkat penghasilan dengan kepatuhan wajib pajak. Semakin meningkat tingkat penghasilan wajib pajak belum tentu memberikan jaminan bahwa wajib 
pajak akan patuh terhadap pajak kendaraan bermotor. Rata-rata tanggapan responden terbanyak di indikator pertanyaan wajib pajak tetap membayar pajak kendaraan bermotor meskipun penghasilan yang dimiliki rendah, hal ini menunjukkan bahwa seberapa banyak ataupun sedikit penghasilan yang wajib pajak punya tidak memberikan pengaruh ketaatan wajib pajak dalam membayarkan pajaknya, ditambah wajib pajak lebih mementingkan untuk memenuhi kebutuhan sehari-hari terlebih dahulu dibanding untuk membayar pajak kendaraan bermotor dan dapat dipastikan bahwa ada alasan lain dari wajib pajak yang mampu menaikkan kepatuhan wajib pajak di bidang tingkat penghasilan yang peneliti tidak cantumkan di indikator pertanyaan kuesioner. Hasil penelitian ini bertolak belakang pada penalitian terdahulu yang telah dilakukan oleh Asrofi Langgeng (2017) dengan judul penelitian analisis sejumlah faktor yang memberikan pengaruh kepatuhan wajib pajak saat membayarkan pajak kendaraan bermotor. Hasil penelitiannya memperlihatkan mengenai variabel tingkat penghasilan memberikan pengaruh secara signifikan pada ketaatan wajib pajak kendaraan bermotor.

\section{Pengaruh Sanksi Perpajakan pada Kepatuhan Wajib Pajak}

Hasil analisa didapat dari uji $\mathrm{t}$ melalui nilai t sejumlah 1,676 dan signifikansi 0,098 melebihi 0,05 berarti tidak ada pengaruh pada sanksi perpajakan dengan kepatuhan wajib pajak. Semakin tinggi sanksi yang diberikan tidak akan mempengaruhi wajib pajak dalam membayar pajak kendaraan bermotor. Tanggapan responden terhadap pertanyaan kuesioner yang diberikan menunjukkan bahwa wajib pajak menyadari jika sanksi diperlukan agar tercipta kepatuhan dalam memenuhi kewajiban perpajakan akan tetapi jika dilihat berdasarkan lingkungan sekitar yang terjadi adalah wajib pajak menyepelekan sanksi yang diberikan. Sanksi perpajakan yang ditetapkan dirasa kurang tegas sehingga wajib pajak yang melanggar peraturan tidak merasa jera untuk mengulanginya lagi. Karena fenomena itu wajib pajak merasakan mengenai sanksi perpajakan hanyalah sekedar peratutan dan tidak berpengaruh pada ketaatan wajib pajak pada pembayaran pajak kendaraan bermotor. Hasil penelitian ini berbeda pada penelitian sebelumnya yang dijalankan oleh Randi Ilhamsyah (2016) dengan judul penelitian pengaruh pemahaman serta wawasan wajib pajak mengenai regulasi perpajakan, kesadaran wajib pajak, mutu pelayanan, serta sanksi perpajakan pada ketaatan wajib pajak kendaraan bermotor. Hasil penelitiannya menunjukkan jika variabel sanksi perpajakan memiliki pengaruh positif serta signikan dengan cara parsial pada ketaatan wajib pajak kendaraan bermotor.

\section{Pengaruh Simultan Variabel Pengetahuan Perpajakan, Kualitas Pelayanan, Tingkat Penghasilan, dan Sanksi Perpajakan pada Kepatuhan Wajib Pajak Kendaraan Bermotor}

Hasil pada uji F dapat diartikan kepatuhan pembayaran pajak kendaraan bermotor di Kabupaten Wonogiri dipengaruhi oleh pengetahuan perpajakan, kualitas pelayanan, tingkat penghasilan, serta sanksi perpajakan. Hasil pengujian pada penelitian ini diperoleh nilai signifikansi $0,000<0,05$ berarti semua variabel bebas dengan cara bersamaan mempengaruhi kepatuhan wajib pajak. Besarnya pengaruh keempat variabel bebas itu saat memberikan pengaruh ketaatan wajib pajak sejumlah $29,3 \%$. Pengaruh dari keempat variabel bebas tersebut terlihat kecil karena sisanya $70,7 \%$ dapat dipastikan diberikan pengaruh melalui variabel bebas yang lain yang tak dipakai pada penelitian ini. Penyebab berpengaruhnya pengetahuan perpajakan, kualitas pelayanan, tingkat penghasilan, serta sanksi perpajakan pada kepatuhan wajib pajak kendaraan bermotor pada Kabupaten Wonogiri yaitu wajib pajak mendeteksi jatuh temponya pembayaran, ruang pelayanan di kantor samsat mencukupi, nyaman serta sejuk jadi memberi rasa nyaman pada wajib pajak, wajib pajak tetap melakukan pembayaran pajak meskipun pendapatan yang mereka miliki rendah, dan wajib pajak merasa mengenai sanksi pajak dibutuhkan supaya terwujudnya kepatuhan saat melakukan pemenuhan kewajiban perpajakan.

\section{Kesimpulan Dan Saran}

Hasil penelitian yang telah dijalankan dideteksi mengenai variabel pengetahuan perpajakan serta kualitas pelayanan berpengaruh signifikan bagi kepatuhan wajib pajak kendaraan bermotor. Variabel tingkat pendapatan serta sanksi perpajakan tidak terdapat dampak bagi ketaatan wajib pajak kendaraan bermotor. Pengaruh dengan cara simultan dideteksi mengenai semua variabel yaitu pengetahuan perpajakan, kualitas pelayanan, tingkat penghasilan serta sanksi perpajakan dengan cara bersamaan memiliki pengaruh pada kepatuhan wajib pajak. Tingkat persentase pengaruh semua variabel bebas tehadap kepatuhan wajib pajak sejumlah 29,3\%.

Keterbatasan penelitian yang terjadi pada penelitian ini yaitu pada saat melakukan pengolahan data, terdapat beberapa jawaban responden yang tidak dapat digunakan sebagai sampel sehingga peneliti harus menggunakan metode outlier yaitu menghilangkan atau menghapus jawaban responden 
yang tidak bisa digunakan untuk melakukan uji hipotesis. Saran untuk peneliti berikutnya supaya lebih fokus serta teliti saat menjalankan olah data serta uji hipotesis, dianjurkan sebelum melakukan olah data peneliti memeriksa terlebih dahulu jawaban - jawaban kuesioner dari responden sebelum dijadikan sebagai alat uji.

\section{Daftar Pustaka}

Ghozali, I. (2016). Aplikasi Analisiss Multivariate dengan Program SPSS. Semarang: Penerbit Universitas Diponegoro.

Haswidar. (2016). Pengaruh Tingkat Pendapatan, Pengetahuan, dan Kesadaran Wajib Pajak Terhadap Kepatuhan Membayar Pajak Bumi dan Bangunan di Kecamatan Pammana Kabupaten Wajo. Skripsi. Universitas Hasanudin. Makasar.

Huda, Nurul., dan Hardius Usman. (2016). Teori dan Aplikasi Statistik - Pendekatan Analisis Ekonomi Islam. Jakarta: Penerbit Prenadamedia Group.

Ilhamsyah., dkk. (2016). Pengaruh Pemahaman dan Pengetahuan Wajib Pajak Tentang Peraturan Perpajakan, Kesadaran Wajib Pajak, Kualitas Pelayanan dan Sanksi Perpajakan Terhadap Kepatuhan Wajib Pajak Kendaraan Bermotor (Studi Samsat Kota Malang). Jurnal Perpajakan (JEJAK), 8(01).

Iqbal, Muhammad A., L. (2018). Faktor - Faktor yang Mempengaruhi Kepatuhan Wajib Pajak dalam Membayar Pajak Kendaraan Bermotor. Skripsi. Universitas Brawijaya Malang.

Isawati, Tri. (2016). Pengaruh Tingkat Pendapatan, Pengetahuan Perpajakan, Pelayanan Pajak serta Sanksi Pajak Terhadap Kepatuhan Wajib Pajak dalam Membayar Pajak Bumi dan Bangunan. Skripsi. Universitas 17 Agustus 1945 Samarinda. Samarinda.

Kotler, P., \& Armstrong, G. (2017). Principles of marketing. United Kingdom : Pearson.

M, Farouq S. (2018). Hukum Pajak di Indonesia. Jakarta: Penerbit Kencana.

Made, I Yuliara. (2016). Modul Regresi Linier Berganda. Bali: Penerbit Universitas Udayana.

Mardiasmo. (2016). Perpajakan Edisi Revisi Tahun 2016. Yogyakarta: Penerbit Andi.

Mardiasmo. (2018). Perpajakan Edisi Revisi Tahun 2018. Yogyakarta: Penerbit Andi.

Melani, M. M., dan Susanti, L. (2018). Analisis Faktor-Faktor yang Mempengaruhi Kepatuhan Wajib Pajak (Studi Kasus pada Kpp Pratama Sukabumi). Jurnal Akunida, 4(1), 47-60.

Meyanti, Theressa Mulyani. (2019). Faktor - Faktor yang Memberikan Kontribusi Terhadap Kepatuhan Wajib Pajak Ojek Online (OJOL) di Jakarta. Jurnal Akuntansi 8(02). Institut Bisnis dan Informatika Kwik Kian Gie.

Mukmin, M. N., dan Maemunah, S. (2019). Pengelolaan Dana Pemerintah Desa Kajian pada Kecamatan Babakan Madang, Sukaraja dan Ciawi. Jurnal Akunida, 4(2), 73-85.

Noor, Juliansyah. (2016). Metode Penelitian - Skripsi. Tesis, dan Karya Ilmiah. Jakarta: Penerbit Kencana.

Pujiasti, Silvy Febriani. (2016). Pengaruh Kesadaran Wajib Pajak dan Kualitas Pelayanan Pajak Terhadap Kepatuhan Wajib Pajak dalam Membayar Pajak Kendaraan Bermotor (Studi Kasus pada Kantor Samsat Kota Bogor). Skripsi Akuntansi. Fakultas Ekonomi Universitas Widyatama.

Pujiwidodo. (2016). Persepsi Sanksi Perpajakan Terdahap Kepatuhan Wajib Pajak Orang Pribadi. Jurnal Online Insan Akuntan, 1(01).

Putra, I. M. A. D., dan Jati, I. K. (2017). Analisis Faktor - Faktor yang Mempengaruhi Kepatuhan Wajib Pajak Kendaraan Bermotor di Kantor Bersama Samsat Tabanan. EJurnal Akuntansi, 557-587. 
Rahayu, N. (2017). Pengaruh Pengetahuan Perpajakan, Ketegasan Sanksi Pajak, dan Tax Amnesty Terhadap Kepatuhan Wajib Pajak. Jurnal Akuntansi Dewantara 1(01). Universitas Sarjanawiyata Taman Siswa.

Resmi, Siti. (2017). Perpajakan. Jakarta: Penerbit Salemba Empat.

Rumiyatun, D. K. K. (2017). Pengaruh Pengetahuan Wajib Pajak , Kesadaran Wajib Pajak, Sanksi Pajak Kendaraan Bermotor, dan Sistem Samsat Drive Thru Terhadap Kepatuhan Wajib Pajak Kendaraan Bermotor (Studi Kasus WP PKB Roda Empat di Samsat Drive Thru Bantul). Jurnal Akuntansi, 5(1).

Samudra, Azhari Aziz. (2016). Perpajakan Indonesia, Keuangan Pajak dan Retribusi Daerah. Jakarta: Penerbit PT Raja Grafindo Persada.

Sugiyono. (2017). Metode Penelitian Kuantitatif, Kualitatif, dan R\&D. Bandung : Penerbit CV Alfabeta.

Sugiyono. (2018). Metode Penelitian Kuantitatif. Bandung: Penerbit CV Alfabeta.

Sumarsan, Thomas. (2017). Perpajakan Indonesia: Pedoman Perpajakan Lengkap Berdasarkan Undang-Undang Terbaru (Edisi 5). Jakarta : Penerbit PT.Indeks.

Usman, Riskia Habiba. (2016). Faktor-Faktor yang Berpengaruh Terhadap Pendapatan Pengrajin Songkok di Kecamatan Gresik Kabupaten Gresik. Jurnal Manajerial, 4(01). Universitas Muhammadiyah Gresik.

Waluyo. (2017). Perpajakan Indonesia. Jakarta: Penerbit Salemba Empat.

Wardani, D. K., \& Rumiyatun, R. (2017). Pengaruh Pengetahuan Wajib Pajak, Kesadaran Wajib Pajak, Sanksi Pajak Kendaraan Bermotor, dan Sistem Samsat Drive Thru Terhadap Kepatuhan Wajib Pajak Kendaraan Bermotor. Jurnal Akuntansi, 5(1), 15-24.

Wardani, D. K., dan Asis, M. R. (2017). Pengaruh Pengetahuan Wajib Pajak, Kesadaran Wajib Pajak, dan Program Samsat Corner Terhadap Kepatuhan Wajib Pajak Kendaraan Bermotor. Jurnal Akuntansi Dewantara, 1(2), 106-116.

Wuryanto, L., U. Sadiati, M.N. Afif. (2019). Faktor - Faktor yang Mempengaruhi Kepatuhan Wajib Pajak dalam Membayar Pajak Kendaraan Bermotor. Jurnal Akunida, 5(02). Universitas Djuanda.

Yuliyanti, Ika. (2016). Pengaruh Pemahaman Wajib Pajak, Kualitas Pelayanan Perpajakan, Sanksi Perpajakan, dan Kondisi Lingkungan Terhadap Tingkat Kepatuhan Wajib Pajak Orang Pribadi. Skripsi. Universitas Muhammadiyah Surakarta. 